\title{
Pharmacological Properties of SM-3997: A New Anxioselective Anxiolytic Candidate
}

\author{
Hiroshi SHIMIZU, Akira HIROSE, Tohru TATSUNO, \\ Mitsutaka NAKAMURA and Junki KATSUBE \\ Research Laboratories, Sumitomo Pharmaceuticals Co., Ltd., \\ 3-1-98. Kasugadenaka, Konohana-ku. Osaka 554, Japan
}

Accepted August 21, 1987

\begin{abstract}
Pharmacological properties of SM-3997 (3a $\alpha, 4 \beta, 7 \beta .7 a \alpha$-hexahydro-2(4-(4- (2-pyrimidinyl) - 1 -piperazinyl) -butyl) - 4,7-methano- $1 \mathrm{H}$-isoindole-1,3(2H)dione dihydrogen citrate) have been examined in rats and mice. SM-3997 showed a dose-related anticonflict activity in rats in a water lick conflict paradigm, and it had no effect on water consumption in a spontaneous water drinking test. The potency of SM-3997 appeared to be equal to that of buspirone and about one-half that of diazepam. No tolerance to the anticonflict activity of SM-3997 was observed following 5 and 10 consecutive days of treatment. Unlike diazepam, SM-3997 had no anticonvulsant effect and had very weak muscle relaxant and hypnotic effects. On the other hand, SM-3997 and buspirone exhibited dopamine antagonistic action, although the potency of SM-3997 was less than one fourth that of buspirone. These results show that SM-3997 is a new anxioselective anxiolytic agent which is weaker than buspirone in the dopaminergic neuron system.
\end{abstract}

Benzodiazepines have been widely used for the treatment of anxiety. They, however, often produce undesirable effects such as drowsiness, ataxia and sedation at clinically effective doses. In addition, they adversely interact with other CNS depressants, particularly alcohol (1). As the occurrence of these side effects may be closely coupled to the mode of action involving benzodiazepine receptors, it is necessary to develop anxiolytics structurally unrelated to the benzodiazepines, which will not interact directly with benzodiazepine receptors.

The compound SM-3997 is a novel nonbenzodiazepine compound possessing potent anxiolytic properties in animal models (2). It does not have the other behavioral actions of benzodiazepines such as muscle relaxant and anticonvulsant activities (2). The present report describes the pharmacological profiles of SM-3997 in comparison with those of diazepam and buspirone, the recently synthesized nonbenzodiazepine anxiolytic (3).

\section{Materials and Methods}

Male Spraque-Dawley rats (200-300 g) and male ddy strain mice $(20-30 \mathrm{~g})$ were used in these studies. All experiments were performed in a room with a $12 \mathrm{hr}$ day-night cycle (dark period: 20:00-08:00 hours) and a relatively constant environment $\left(24 \pm 1^{\circ} \mathrm{C}\right.$ and $55 \pm 5 \%$ relative humidity), and all animals received food and water ad libitum except when indicated. The ED50 value was calculated according to the method of Litchfield and Wilcoxon (4). Drugs were administered in volumes of $10 \mathrm{ml} / \mathrm{kg}$ for all routes in rats and mice except in the conflict test. In the conflict test, drugs were administered in volumes of $5 \mathrm{ml} / \mathrm{kg}$ for all routes in rats.

\section{Anticonflict activity}

A modification of the method of Vogel et al. (5) was used. Rats were deprived of water for $24 \mathrm{hr}$ prior to the first training session (unpunished session) consisting of a $3 \mathrm{~min}$ period. Each animal was then placed in a 
plexiglass conflict test box $(38 \times 38 \times 20 \mathrm{~cm})$. A water bottle with a stainless steel spout was fitted to the middle of the outside of one of the sides so that the spout extended $1 \mathrm{~cm}$ into the box at a height of $2 \mathrm{~cm}$ above the floor. The rat was allowed to explore until it discovered the drinking spout and began to drink. The number of licks at the spout in $3 \mathrm{~min}$ was counted. Only rats making more than 300 licks during the $3 \mathrm{~min}$ unpunished session progressed to a further $24 \mathrm{hr}$ deprivation of water. Twenty four hours after the unpunished session (48 hr after access to water), the rat was placed in the test box. The second session (pre-drug punished session) consisting of a $3 \mathrm{~min}$ period started automatically when the rat completed 20 licks and received the first mild electric shock $(0.35 \mathrm{~mA}, 0.5$ $\mathrm{sec})$. After every 20 unpunished licks, subsequent licking was punished. Only rats showing suppression of licking (less than 260 licks) by punishment during the pre-drug punished session by comparison with the unpunished session were included in the study. Each animal was used only once.

Drugs were administered $30 \mathrm{~min}$ after the pre-drug punished session. Then the $3 \mathrm{~min}$ post-drug punished session was repeated after the administration of SM-3997. buspirone and diazepam.

1.1. Single administration test: The number of shocks taken in the $3 \mathrm{~min}$ post-drug punished session was measured at $1 \mathrm{hr}$ after the oral or i.p. administration of SM-3997 and buspirone, and at $30 \mathrm{~min}$ after diazepam.

1.2. Repeated administration test: $S M$ 3997 (10 mg/ $/ \mathrm{kg}$ ), buspirone (10 $\mathrm{mg} / \mathrm{kg}$ ) and diazepam $(5 \mathrm{mg} / \mathrm{kg}$ ) were injected i.p. continuously for 5 or 10 days, and the number of shocks taken in the 3 min post-drug punished session was measured at $1 \mathrm{hr}$ (SM3997 and buspirone) and $30 \mathrm{~min}$ (diazepam) after the last administration of each drug.

1.3. Spontaneous water drinking test: In order to measure water intake. the same apparatus in the conflict procedure was used. Rats were deprived of water for $24 \mathrm{hr}$ prior to the first training session consisting of a $3 \mathrm{~min}$ period. Only rats making more than 300 licks during the 3 min training session progressed to a further $24 \mathrm{hr}$ deprivation of water. Twenty four hours after the training session (48 hr after access to water), the rat was placed in the test chamber. Water consumption sessions consisting of $3 \mathrm{~min}$ periods, starting automatically when the rat completed 20 licks, were repeated at $1 \mathrm{hr}$ after the oral administration of SM-3997 and buspirone, and at $30 \mathrm{~min}$ after diazepam.

\section{Muscle relaxant action}

2.1. Traction test: This experiment was carried out according to the method described by Couvoisier et al. (6). Mice were hung on the horizontal wire $(1 \mathrm{~mm}$ diameter, $30 \mathrm{~cm}$ in height) by the forepaws at $1 \mathrm{hr}$ after the oral administration of SM-3997 and buspirone, and at $30 \mathrm{~min}$ after diazepam. If the hindpaws of the mouse did not touch the wire within 10 sec in 3 successive trials, a positive response was noted.

2.2. Rota-rod test: This experiment was carried out according to the method described by Dunham and Miya (7). Mice and rats were gently placed on the rota-rod $(5 \mathrm{~cm}$ in diameter for mice and $8 \mathrm{~cm}$ in diameter for rats, $5 \mathrm{rpm}$ ) at $1 \mathrm{hr}$ after the oral administration of SM-3997 and buspirone, and at $30 \mathrm{~min}$ after diazepam. If the animals fell from the rotating rod within $60 \mathrm{sec}$, a positive response was noted.

\section{Potentiation of anesthesia}

3.1. Potentiation of the hexobarbitalinduced anesthesia: Hexobarbital at a dose of $140 \mathrm{mg} / \mathrm{kg}$ was injected i.p. at $1 \mathrm{hr}$ after the oral administration of SM-3997 and buspirone, and at $30 \mathrm{~min}$ after diazepam. The anesthetic interval was recorded for each mouse by measuring the time between the loss and the recovery of the righting reflex. The ED50 was calculated by determining the dose needed to prolong the anesthetic interval to a level two times the average value of the controls in $50 \%$ of the mice.

3.2. Potentiation of the ethanol-induced anesthesia: Ethanol at a dose of $3 \mathrm{~g} / \mathrm{kg}$ was injected i.p. at $1 \mathrm{hr}$ after the oral administration of SM-3997 and buspirone, and at $30 \mathrm{~min}$ after diazepam. At $45 \mathrm{~min}$ thereafter. the ED50 value for causing the loss of the righting reflex was determined.

\section{Effect on convulsion}

Mice were challenged with pentylenetetrazole $(110 \mathrm{mg} / \mathrm{kg}$. s.c.). bicuculline $(0.6$ $\mathrm{mg} / \mathrm{kg}$, i.v.) or maximum electroshock (MES; 


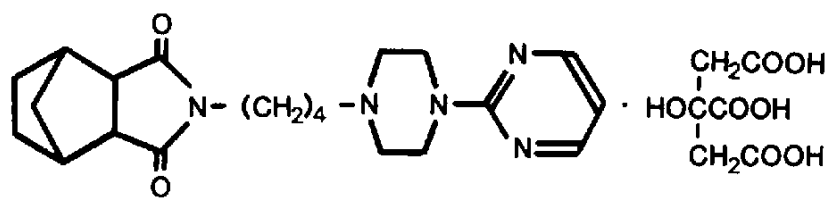

Fig. 1. Chemical structure of SM-3997

$15 \mathrm{~mA}, 0.2 \mathrm{sec}$ duration) delivered through corneal electrodes at $1 \mathrm{hr}$ after the oral administration of SM-3997 and buspirone. and at 30 min after diazepam. The dose which prevented clonic (pentylenetetrazole) or tonic (bicuculline and MES) convulsions for $30 \mathrm{~min}$ following the injection of drugs or the application of maximum electric shock in 50\% of the mice was defined as the ED50.

\section{Effect on dopamine systems}

5.1. Anti-apomorphine test in rats: Rats were challenged by apomorphine $(0.5 \mathrm{mg} /$ $\mathrm{kg}$, i.v.) at $1 \mathrm{hr}$ after the oral administration of SM-3997, buspirone and diazepam. If the rat showed no licking behavior for $20 \mathrm{~min}$ after the injection of apomorphine, a positive response was noted.

5.2. Anti-apomorphine test in mice: Mice were challenged by apomorphine $(1 \mathrm{mg} / \mathrm{kg}$. s.c.) at $1 \mathrm{hr}$ after the oral administration of SM-3997 and buspirone. If the mouse showed no climbing behavior for $10 \mathrm{~min}$ at 10 min after the injection of apomorphine. a positive response was noted.

5.3. Anti-methamphetamine test: Mice were challenged by methamphetamine (1 $\mathrm{mg} / \mathrm{kg}$, i.p.) at $30 \mathrm{~min}$ after the oral administration of SM-3997 and buspirone. The dose which prevented spontaneous locomotor activity for $1 \mathrm{hr}$ at $10 \mathrm{~min}$ after the injection of methamphetamine in 50\% of the mice was defined as the ED50.

5.4. Conditioned avoidance test in a shuttle box: Rats were allowed to adapt to the shuttle box for 30 min on the first day and then given $6.5 \mathrm{~min}$ training sessions (13 trials/session) daily. The conditioned stimulus (CS) was the sound of a buzzer, and the unconditioned stimulus (UCS) was intermittent electric shock. The CS-UCS interval was $5 \mathrm{sec}$. The escape response was a movement from one compartment to the other after the onset of shock. The avoidance response was a similar movement made during the 5 sec CS-UCS interval. Training was carried to a criterion of $90 \%$ avoidance responses in 13 trials. After reaching the criterion, the rats were injected with SM-3997 and buspirone. At $1 \mathrm{hr}$ after this injection, the rats were returned to the shuttle box and tested for $6.5 \mathrm{~min}$. A positive response was scored if the rat received 2 or more shocks within 10 trials after a 3 trial initiation period. 6 . Influence on spontaneous locomotor activity (SLA)

A mouse was placed in a photocell activity cage at $1 \mathrm{hr}$ after the oral administration of SM-3997 and buspirone or at $30 \mathrm{~min}$ after diazepam. The count during $10 \mathrm{~min}$ was taken as the spontaneous locomotor activity of a mouse. A positive response was scored if the locomotor activity of drug-treated mice decreased by $50 \%$ of the activity of the vehicle-treated control groups.

\section{Drugs}

SM-3997 citrate (Fig. 1), buspirone $\mathrm{HCl}$ and diazepam were synthesized at the Sumitomo Pharmaceuticals Co., Ltd. Other chemicals were obtained from standard commercial sources.

SM-3997, buspirone, pentylenetetrazole (Aldrich), apomorphine $\mathrm{HCl}$ (Sandoz) and methamphetamine $\mathrm{HCl}$ (Dainihon-Seiyaku) were dissolved in saline $(0.9 \% \mathrm{NaCl})$. Diazepam was suspended in a $0.5 \%$ methylcellulose solution. Bicuculline (Sigma) was dissolved in $0.01 \mathrm{~N} \mathrm{HCl}$ solution and hexobarbital (Teikoku-Kagaku) in $0.01 \mathrm{~N}$ $\mathrm{NaOH}$ solution. All control animals received the appropriate vehicle.

8. Statistical analysis

Dunnett's test was used for statistical analysis of the data.

\section{Results}

\section{Anticonflict activity}

1.1. Single administration test: $S M-3997$ produced a significant increase in the number 
of shocks at doses of 5 and $10 \mathrm{mg} / \mathrm{kg}$. i.p. or 20 and $40 \mathrm{mg} / \mathrm{kg}$, p.o. Buspirone and diazepam also produced a dose-related and significant increase in the number of shocks (Fig. 2). The relative potency of SM-3997 appeared to be equal with that of buspirone and about one-half that of diazepam.

1.2. Repeated administration test: $S M$ 3997 (10 mg/kg. i.p.), buspirone (10 mg/ $\mathrm{kg}$, i.p.) and diazepam $(5 \mathrm{mg} / \mathrm{kg}$, i.p.) produced
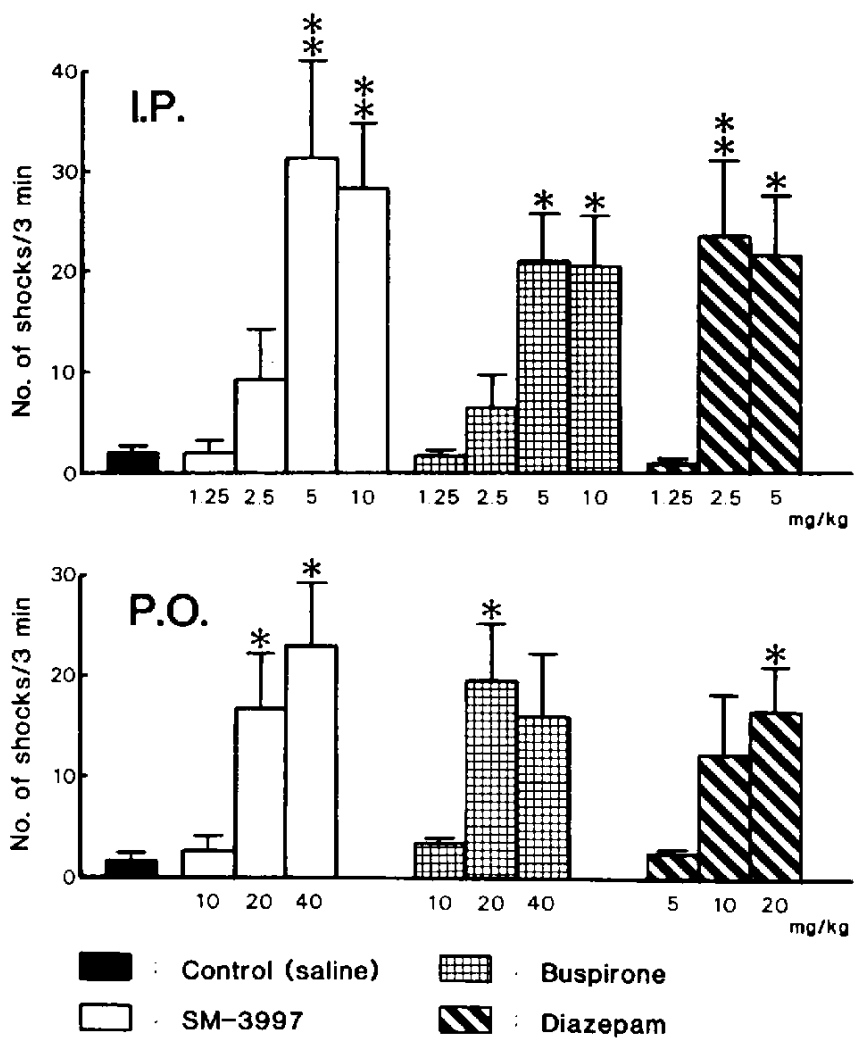

Fig. 2. Effects of SM-3997, buspirone and diazepam on the shock-induced suppression of the drinking test. The data are represented as mean valuestS.E.M. $(n=10)$. The significance of the difference from the control is represented by asterisks ( $P<0.05,{ }^{* *} P<0.01$. by Dunnett's test).

Table 1. Anticonflict activity following single and repeated (5 and 10 days) administration of SM-3997, buspirone and diazepam in rats

\begin{tabular}{|c|c|c|c|c|c|c|}
\hline \multirow{2}{*}{ Drugs } & \multirow{2}{*}{ Days } & \multirow{2}{*}{$\begin{array}{c}\text { Dose } \\
(\mathrm{mg} / \mathrm{kg} \text {, i.p.) }\end{array}$} & \multicolumn{4}{|c|}{ Punished responding ${ }^{\prime}$} \\
\hline & & & Single & $(n)^{2}$ & Repeated & $(n)^{2}$ \\
\hline Control & 5 & 0 & $2.1 \pm 0.6$ & (10) & $1.0 \pm 0.5$ & (10) \\
\hline SM-3997 & 5 & 10 & $28.3 \pm 6.4^{* *}$ & (10) & $25.2 \pm 5.9^{* *}$ & (11) \\
\hline Diazepam & 5 & 5 & $21.5 \pm 5.8^{* *}$ & $(10)$ & $24.7 \pm 4.9^{* *}$ & $(10)$ \\
\hline Control & 10 & 0 & $2.1 \pm 0.6$ & (10) & $3.1 \pm 1.2$ & (12) \\
\hline SM-3997 & 10 & 10 & $28.3 \pm 6.4^{* *}$ & $(10)$ & $28.1 \pm 2.8^{* *}$ & (10) \\
\hline Buspirone & 10 & 10 & $20.5 \pm 5.1^{* *}$ & $(10)$ & $18.5 \pm 3.1^{* *}$ & $(10)$ \\
\hline
\end{tabular}

1 Mean shocks \pm S.E.M. in 3 min. ${ }^{2}$ Number of rats tested. ${ }^{* *} P<0.01$. Significantly different from the control (Dunnett's test). 
Table 2. Effects of SM-3997, buspirone and diazepam on the spontaneous drinking behavior of rats

\begin{tabular}{lcc}
\hline Drugs & $\begin{array}{c}\text { Dose } \\
(\mathrm{mg} / \mathrm{kg} . \mathrm{p.o})\end{array}$ & Water drinking ${ }^{1}$ \\
\hline Control & 0 & $25.6 \pm 3.1$ \\
SM-3997 & 20 & $32.3 \pm 3.6$ \\
& 40 & $28.7 \pm 3.7$ \\
Buspirone & 80 & $28.6 \pm 3.7$ \\
& 160 & $19.6 \pm 5.4$ \\
& 20 & $30.6 \pm 2.3$ \\
Control & 40 & $25.4 \pm 3.5$ \\
Diazepam & 80 & $24.1 \pm 3.0$ \\
& 160 & $5.0 \pm 2.7^{*}$ \\
& 0 & $24.7 \pm 3.7$ \\
& 5 & $34.9 \pm 3.0$ \\
& 10 & $40.5 \pm 3.3^{* *}$ \\
\hline
\end{tabular}

1 (Mean \pm S.E.M.) $\times 20$ licks in 3 min. $\quad * * 0<0.01$ Significantly different from the control.

a significant increase in the number of shocks following repeated administration for 5 or 10 days (Table 1 ). There was no significant difference among the single and 5 or 10 days repeated administration groups.

1.3. Spontaneous water drinking test: The comparative effects of SM-3997, buspirone and diazepam on spontaneous drinking behavior of rats are presented in Table 2 . SM-3997 had no significant effect on the number of licks at doses up to $160 \mathrm{mg} / \mathrm{kg}$. p.o. Buspirone, however, significantly decreased it at $160 \mathrm{mg} / \mathrm{kg}$, p.o. In contrast, diazepam produced a significant increase in the number of licks at doses of 10 to $40 \mathrm{mg} /$ kg, p.o.

\section{Muscle relaxant action}

The comparative muscle relaxant activities of SM-3997, buspirone and diazepam in the traction and rota-rod test are presented in Table 3. In the traction test, SM-3997, like buspirone, did not induce muscle relaxation at doses up to $300 \mathrm{mg} / \mathrm{kg}$, p.o. Whereas diazepam caused muscle relaxation at relatively low doses (ED50: $3.9 \mathrm{mg} / \mathrm{kg}$, p.o.) in the same test.

SM-3997 and buspirone impaired rota-rod performance at relatively high doses in mice and rats. The ED50 values of SM-3997 in mice and rats were $207 \mathrm{mg} / \mathrm{kg}$, p.o. and greater than $300 \mathrm{mg} / \mathrm{kg}$, p.o., respectively, and those of buspirone in mice and rats were
$172 \mathrm{mg} / \mathrm{kg}$, p.o. and $125 \mathrm{mg} / \mathrm{kg}$, p.o.. respectively. In contrast, diazepam impaired rota-rod performance at relatively low doses. The ED50 values were $2.1 \mathrm{mg} / \mathrm{kg}$. p.o., in mice and $9.1 \mathrm{mg} / \mathrm{kg}$, p.o., in rats.

\section{Potentiation of anesthesia}

SM-3997 and buspirone increased the duration of the hexobarbital-induced anesthesia at relatively high doses. The ED50 value of SM-3997 was $212 \mathrm{mg} / \mathrm{kg}$, p.o., and that of buspirone was $263 \mathrm{mg} / \mathrm{kg}$, p.o. They. however, failed to increase the duration of the anesthesia induced by ethanol at doses up to $300 \mathrm{mg} / \mathrm{kg}$, p.o. In contrast, diazepam produced a significant potentiation of the anesthesia induced by these two drugs at relatively low doses. The ED50 values of diazepam were $1.8 \mathrm{mg} / \mathrm{kg}$. P.o., in the hexobarbital test and $3.0 \mathrm{mg} / \mathrm{kg}, 0.0$., in the ethanol test (Table 3).

\section{Effect on convulsion}

SM-3997 and buspirone failed to inhibit the convulsion induced by pentylenetetrazole. bicuculline and MES at doses up to $300 \mathrm{mg} /$ $\mathrm{kg}$, p.o., in mice. In contrast, diazepam antagonized the convulsion induced by pentylenetetrazole, bicucultine and MES at relatively low doses. The ED50 values of diazepam were $0.41 \mathrm{mg} / \mathrm{kg}$, p.o., in the pentylenetetrazole test; $1.2 \mathrm{mg} / \mathrm{kg}$, p.o., in the bicuculline test: and $5.9 \mathrm{mg} / \mathrm{kg}$, p.o., in the MES test (Table 3). 
Table 3. Comparison of the pharmacological actions of SM-3997, buspirone and diazepam in various behavioral tests in mice and rats

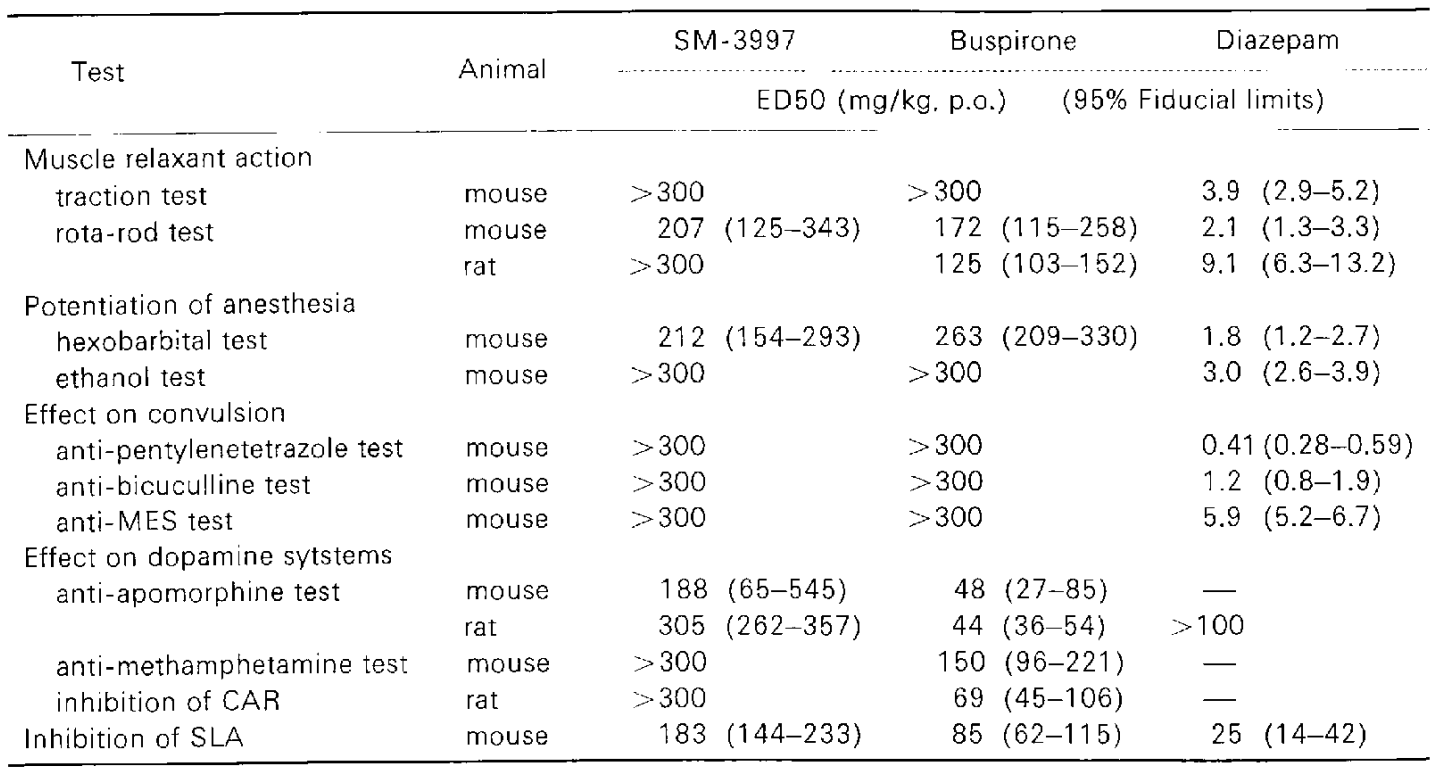

Ten mice and five rats were used at each dose: 3 to 5 doses of test drugs were tested. MES: maximum electroshock. CAR: conditioned avoidance response. SLA: spontaneous locomotor activity.

\section{Effect on dopamine systems}

5.1. Anti-apomorphine test in rats and mice, and anti-methamphetamine test in mice: SM-3997 exhibited the anti-apomorphine activity in mice and rats at relatively high doses (ED50: $188 \mathrm{mg} / \mathrm{kg}$, p.o. and $305 \mathrm{mg} / \mathrm{kg}$, p.o., respectively). SM-3997. however, failed to inhibit the hyperactivity induced by methamphetamine in mice at doses up to $300 \mathrm{mg} / \mathrm{kg}$, p.o. In contrast, buspirone produced a significant inhibition in these three tests. The ED50 values of buspirone were $48 \mathrm{mg} / \mathrm{kg}$, p.o., in the antiapomorphine test in mice; $44 \mathrm{mg} / \mathrm{kg}$, p.o., in the anti-apomorphine test in rats; and $150 \mathrm{mg} / \mathrm{kg}$, p.o., in the anti-methamphetamine test in mice. Diazepam did not have an anti-apomorphine action in rats at doses up to $100 \mathrm{mg} / \mathrm{kg}$, p.o. (Table 3).

5.2. Conditioned avoidance test in a shuttle box: SM-3997 failed to inhibit the conditioned avoidance response (CAR) in rats at doses up to $300 \mathrm{mg} / \mathrm{kg}$. p.o. Buspirone, however, inhibited the CAR at relatively low doses (ED50: $69 \mathrm{mg} / \mathrm{kg}$, p.o.) (Table 3)

\section{Influence on spontaneous locomotor}

\section{activity (SLA)}

SM-3997, buspirone and diazepam decreased the spontaneous locomotor activity of mice in a dose-related manner. Their ED50 values were $183 \mathrm{mg} / \mathrm{kg}$, p.o., $85 \mathrm{mg} / \mathrm{kg}$. p.o. and $25 \mathrm{mg} / \mathrm{kg}$, p.o., respectively. The relative potency of SM-3997 was about one-half that of buspirone and about one seventh that of diazepam (Table 3).

\section{Discussion}

It is well-known that in Vogel's conflict procedure, the anticonflict action predicts clinical anxiolytic activity (8), and there have been many reports showing that benzodiazepines with clinical anxiolytic activity were effective in this test. The compound buspirone, whose structure and pharmacological profile are different from those of the benzodiazepines, has also been shown to induce anxiolytic activity in clinical studies $(9$, 10). It is, however, not clear that buspirone exhibits anticonflict activity in the conflict model. It has been reported that buspirone was active at doses of 20 to $80 \mathrm{mg} / \mathrm{kg}$. p.o. (11) or 1 to $5 \mathrm{mg} / \mathrm{kg}$, p.o. (12) in Vogel's conflict procedure, although Goldberg and 
Finnerty (9) and Sanger et al. (13) have not found anticonflict activity of buspirone in the same test. Significant differences in the two methods may explain this discrepancy. In the present study, we have observed that buspirone exhibited clear effects in Vogel's conflict test at 20 to $40 \mathrm{mg} / \mathrm{kg} . \mathrm{p} .0$. or 5 to $10 \mathrm{mg} / \mathrm{kg}$, i.p. Furthermore, the new compound SM-3997 was also effective in a dose-dependent fashion after i.p. and p.o. administration in this test. The efficacy of SM-3997 was equipotent to that of buspirone and was weaker than diazepam. This shows that SM-3997 will have clinically anxiolytic activity like diazepam and buspirone.

Since the conflict model in this study utilizes the primary drive of thirst to motivate the subject's behavior. it is possible that agents that affect the primary drive state could alter the animal's performance in such a procedure. For example, the hypertonic saline that increased water consumption exhibited significant anticonflict activity in the conflict model (14). Similarly, diazepam produced an increase in water consumption in rats. This result suggests that the effects of diazepam on the primary drive might be partly related to its anticonflict activity in this conflict model. On the other hand. SM3997 failed to enhance water consumption in rats. This suggests that the anticonflict activity of SM-3997 is primarily due to its anxiolytic potential.

It is generally believed that tolerance to the anxiolytic activity of the benzodiazepines does not develop. We observed that tolerance to the anticonflict activity of diazepam did not develop. which is similar to the results reported by Margules and Stein (15). Furthermore, SM-3997 also exhibited the anticonflict activity following 5 or 10 daily administrations as well as single administration. These results suggest that there might be no development of tolerance to the putative anxiolytic activity of SM-3997.

Diazepam induced muscle relaxation and potentiation of anesthesia induced by hexobarbital and ethanol at doses close to anxiolytic doses. In contrast, SM-3997 showed a wide separation between anxiolytic activity and ability to cause muscle relaxation and was shown to potentiate anesthesia induced by hexobarbital and ethanol. This indicates that SM-3997 might lack side effects like drowsiness, sedation and ataxia which were often produced by diazepam. Likewise, the interaction with alcohol and CNS depressants, compared with diazepam. may be less pronounced in the case of SM3997.

SM-3997 and buspirone exhibited dopamine antagonistic action, although the potency of SM-3997 was less than one fourth that of buspirone. Wood et al. (16) have reported that buspirone produces a potent and dose-dependent increase in striatal DA metabolites (DOPAC and HVA) like haloperidol. Moreover, it has been reported that buspirone, due to its antidopamine activity, has weak neuroleptic activity and has shown extrapyramidal side effects in clinical study (17) and prolactin releasing activity in rats (18) and humans (19). It can be expected that SM-3997 is less likely to induce these actions than buspirone.

It is now generally accepted that the action of benzodiazepine anxiolytics is mediated via the benzodiazepine-GABA receptor complex in the CNS (20). SM-3997, however, did not bind to benzodiazepine receptors or GABA receptors, and it did not potentiate benzodiazepine or GABA binding to each receptor (21). The anticonflict action of SM-3997 was not inhibited by the benzodiazepine antagonist (e.g., Ro 151788 or CGS 8216) or a GABA antagonist (e.g., bicuculline) (2). Moreover, SM-3997 did not antagonize the convulsion induced by bicuculline. These results indicate that SM3997 does not have a direct action on the benzodiazepine-GABA receptor complex and may have a mechanism of action which does not include the benzodiazepine-GABA receptor complex. On the other hand, we found that SM-3997 bound preferentially to a special subtype (5-HT ${ }_{14}$ receptors) of $5-\mathrm{HT}$ receptors, and it showed some effects on the 5-HT behavioral syndrome such as the flat body posture in rats (21). Moreover, in binding studies with radiolabelled SM-3997. it was indicated that ${ }^{3} \mathrm{H}-\mathrm{SM}-3997$ bound selectively and with high affinity to $5-\mathrm{HT}-1 \mathrm{~A}$ receptors in rat brain, and it may be an 
agonist for its binding sites (22). Therefore the pharmacological action of SM-3997 may be produced via the 5-HT neuron system, and is unrelated to the benzodiazepine-GABA receptor complex. Further work is in progress to clarify the mechanism of action of SM3997 in more detail.

\section{References}

1 Palva, E.S., Linnoila, M., Saario, I. and Mattila, M.: Acute and subacute effects of diazepam on psychomotor skills; Interactions with alcohol. Acta Pharmacol. Toxicol. 45, 257-264 (1979)

2 Hirose, A., Kato, T., Shimizu, H., Nakamura, M. and Katsube, J.: The pharmacological properties of SM-3997. Japan. J. Pharmacol. 40, Supp. $114 \mathrm{P}(1986)$

3 Riblet, L.A., Taylor, D.P., Eison, M.S. and Stanton, H.C.: Pharmacology and neurochemistry of buspirone. J. Clin. Psychiaty 43, 11-18 (1982)

4 Litchfield, J.T, and Wilcoxon, F.: A simplified method of evaluating dose-effect experiments. J. Pharmacol. Exp. Ther. 96, 99-113 (1949)

5 Vogel, J.R., Beer, B. and Clody, D.E.: A simple reliable conflict procedure for testing antianxiety agents. Psychopharmacology (Berlin) 21, 1-7 (1971)

6 Couvoisier, S., Ducrot, R. and Julor, L.: Nouveaux aspects experimentaux de l'activité centrale des dérives de la phenothiazine. In Psychotropic Drugs, Edited by Garattini. U., p. 373-391, Elsevier, Amsterdam (1957)

7 Dunham, N.W. and Miya, T.S.: A note on a single apparatus for detecting neurological defict in rats and mice. J. Am. Pharm. Assoc. 46, 208209 (1957)

8 Cook, L. and Davidson, A.B.: Effects of behaviorally active drugs in a conflict-punishment procedure in rats. In The Benzodiazepines, Edited by Garattini, S., Mussini, E. and Randall, L.O.. p. 327-345. Raven Press, New York (1973)

9 Goldberg, H.L. and Finnerty, R.J.: Comparative efficacy of buspirone and diazepam in treatment of anxiety. Am. J. Psychiatry 136, 1184-1187 (1979)

10 Rickels, K., Weissman, K., Norstad, N., Sinsger, M., Stoltz, D., Brown, $A$ and Danton, J.: Buspirone and diazepam in anxiety: A controlled study. Clin. J. Psychiatry 43 (Sec. 2), 81-86 (1982)
11 Oakley, N.R. and Jones, B.J.: Buspirone enhances ${ }^{3} \mathrm{H}$-flunitrazepam binding in vivo. Eur. J. Pharmacol. 87, 499-500 (1983)

12 Weissman, B.A., Barrett, J.E., Brady, L.S., Witkin, J.M., Mendelson, W., Paul, S.M. and Skolnick, P.: Behavioral and neurochemical studies on the anticonflict actions of buspirone. Drug Dev. Res. 4, 83-93 (1984)

13 Sanger, D.J., Joly, D. and Zivkovic, B.: Behavioral effects of nonbenzodiazepine anxiolytic drugs: A comparision of CGS 9896 and zopiclone with chlordiazepoxide. J. Pharmacol. Exp. Ther. 232, 831-837 (1985)

14 Gardner, C.R. and Piper, D.C.: Effects of adrenoceptor modulation on drinking conflict in rats. Br. J. Pharmacol. 75, 50P (1982)

15 Margules, D.L. and Stein, L.: Increase of "antianxiety" activity and tolerance of behavioral depressions during chronic administration of oxazepam. Psychopharmacology (Berlin) 13, 78-80 (1968)

16 Wood, P.L., Nair, N.P.V., Lal, S. and Etienne, P.: Buspirone: a potential atypical neuroleptic. Life Sci. 33, 269-273 (1983)

17 Sathananthan, G.L., Sanghvi, I., Phillips, N. and Gershon, S.: MJ 9022: Correlation between neuroleptic potential and stereotypy. Curr. Ther. Res. 18, 701-705 (1975)

18 Meltzer, H.Y., Simonovic, M., Fang, V.S. and Gudelsky, G.A.: Effects of buspirone on rat plasm prolactin levels and striatal dopamine turnover. Psychopharmacology (Berlin) 78, 4953 (1982)

19 Meltzer, H.Y., Flemming, R. and Robertson, A.: The effect of buspirone on prolactin and growth hormone secretion in man. Arch. Gen. Psychiatry 40, 1099-1102 (1983)

20 Lippa, A.S., Meyerson, L.R. and Beer, B.: Molecular substrates of anxiety: Clues from the heterogeneity of benzodiazepine receptors. Life Sci. 31, 1409-1417 (1982)

21 Shimizu, H., Hirose, A., Karai, N., Tatsuno, T., Nakamura, M. and Katsube. J.: The mechanism of the pharmacological action of SM-3997: A new anxioselective anxiolytic agent. Japan J. Pharmacol. 40, Supp. 191P (1986)

22 Shimizu, H., Tatsuno, T., Hirose, A., Nakamura, $M$. and Katsube, J.: Characterization of the putative anxiolytic SM-3997 recognition sites in rat brain. Japan J. Pharmacol. 43, Supp. 59p (1987) 